\title{
COVARIANCE BASED-SEM ON RELATIONSHIP BETWEEN DIGITAL LITERACY, USE OF E-RESOURCES, AND READING CULTURE OF STUDENTS*
}

\author{
Reny Rian Marliana ${ }^{1 \ddagger}$, Leni Nurhayati ${ }^{2}$ \\ 1Department of Informatics Engineering, STMIK Sumedang, Indonesia, renyrianmarliana@gmail.com \\ 1Department of Informatics Management, STMIK Sumedang, Indonesia, leninurhayati82@gmail.com \\ Fcorresponding author
}

Indonesian Journal of Statistics and Its Applications (eISSN:2599-0802) Vol 4 No 1 (2020), 55 - 67

Copyright (C) 20xx Reny Rian Marliana and Leni Nurhayati. This is an open-access article distributed under the Creative Commons Attribution License, which permits unrestricted use, distribution, and reproduction in any medium, provided the original work is properly cited.

\begin{abstract}
In this paper, a relationship model among latent variables using Covariance BasedStructural Equation Modeling (CB-SEM) is studied. The latent variables are digital literacy, use of e-resources and reading culture of students. The goal of the study is to build a simultaneously model between those three variables, determine the influence of digital literacy on the use of e-resources and reading culture of students, and the influence of the use of e-resources on reading culture of students. The parameters of the model are estimated by the Maximum Likelihood method. This study took data from 256 questionnaires of students at STMIK Sumedang. Results showed that digital literacy significantly influences the use of e-resources and the reading culture of students. In contrast, there are no significant influences on the use of e-resources on the reading culture of the student.
\end{abstract}

Keywords: cb-sem, digital literacy, use-of e-resources, reading culture, covariance based

\section{Introduction}

Structural Equation Modeling (SEM) is one of the most widely applied methodologies to analyze the relationship between latent variables. Latent variables in SEM generally correspond to hypothetical construct or explanatory entities presumed to reflect a continuum which is not directly observable and can represent a wide range of phenomena (Kline, 2016). In this research, three latent variables i.e. digital literacy, the use of e-resources and the reading culture of students are studied. These variables are not directly observable, but they observed through each construct. An observed variable used as an indirect measure of a construct is an indicator, and the statistical realization of a construct based on analyzing scores from its indicators is a factor (Kline,

"Received Aug 2019; Accepted Des 2019; Published online on Feb 2020 
2016). The indicators of constructs for digital literacy (Kurniawati \& Baroroh, 2016; Nasrullah et al., 2017; Nurjanah et al., 2017a), the use of e-resources (Abubakar, 2015; Adeleke et al., 2017; Akussah \& Adu-sarkodee, 2015; Ani et al., 2015; Bala, 2016; Egberongbe, 2011; Imsong, 2016; Madondo et al., 2017; Noreh, 2009; Nurjanah et al., 2017a) and reading culture of students (Periyeti, 2017; Sapril, 2010) can be seen at Figure 1.

Some studies showed that there is a significant relationship between digital literacy and the use of e-resources. Nurjanah et al. (2017) showed that digital literacy has a high correlation with the use of e-resources. Egberongbe (2011), Noreh (2009), Bala (2016), Madondo et al. (2017) and Akussah et al. (2015) showed that low use of eresources caused by low digital literacy. The concept of digital literacy refers to literacy activities that inseparable from reading, writing, and mathematics related to Education (Nasrullah et al., 2017; Yanti, 2016). One component of digital literacy is the basic ability of digital literacy which includes an ability to read, write, understand symbols in representing languages and calculate numbers (Nurjanah et al., 2017a). Clear that digital literacy has a reciprocal relationship with the reading culture. Another study showed that the use of e-resources has a relationship with the reading culture. Bala (2016) and Ajayi (2014) indicate that the use of e-resources can improve the reading culture of students. The use of e-books increases the time and frequency of reading students (Akpokodje \& Ukwuoma, 2016). From those studies, if digital literacy and the reading culture of students increase, it is expected that the use of e-resources will be higher than the use of unreliable sources. Thus, not only the quality of the academic assignments of students will improve, but also the quality of the students and graduates will increase.

Relationship analysis between these three variables is separate. Nurjanah et al. (2017) used Pearson product-moment correlation to analysis of the relationship between digital literacy and the use of e-resources. Egberongbe (2011), Noreh (2009), Bala (2016), Madondo et al. (2017) and Akussah et al. (2015) used descriptive statistics. Separately, the relationship modeling between the use of e-resources and reading culture also used descriptive statistics (Ajayi, 2014; Akpokodje \& Ukwuoma, 2016; Bala, 2016). While, the relationship between digital literacy and reading culture is studied based on the definition of literacy (Kurniasih, 2016; Nasrullah et al., 2017; Nurjanah et al., 2017a; Yanti, 2016).

The use of descriptive statistics and Pearson product-moment correlation to analyze the relationships of those three variables cannot interpret the relationship between the indicators of the constructs and their latent variable. To make a relationship modeling more effective, a simultaneously model that can analyze the relationship between digital literacy, the use of e-resources and the reading culture of students is needed. The simultaneous relationship modeling can be used to know not only the influence of digital literacy on the use of resources, the influence of digital literacy on the reading culture of students, the influence of using e-resources on the culture of reading students, but also can interpret the relationship between these three variables and their indicators of the construct (see Figure 1). As we mentioned before, one of the statistical analysis that can be used is Structural Equation Modeling (SEM).

SEM has two approaches, i.e. Covariance Based-Structural Equation Modeling (CB-SEM) and Partial-Least Square Structural Equation Modeling (PLS-SEM) (Hair, M.Hult, et al., 2014; Jr et al., 2014; Wong \& Wong, 2013). CB-SEM is used when the goal of the study is to test a theory, confirm a theory and compare several alternative theories with large sample sizes and normally distributed data (Hair, M.Hult, et al., 2014; Jr et al., 2014; Wong \& Wong, 2013). Whereas, PLS-SEM is a nonparametric 
method that does not need distribution assumptions from data. PLS-SEM can be used on data that is not normally distributed. The PLS algorithm transforms abnormal data through the central limit theorem (Jr et al., 2014).

CB-SEM aims to confirm theories by determining how well a model can estimate a covariance matrix for the sample data, while PLS-SEM operates much like a multiple regression analysis (Jr et al., 2014). Estimation procedures for PLS-SEM are based on an Ordinary Least Squares (OLS) method and the Maximum Likelihood (ML) method for CB-SEM. Unlike CB-SEM, PLS-SEM focus on composites, composites aggregate indicators but do not fully incorporate measurement error and only viewed as approximations of factors, it causes the method yield biased estimates of various parameters even as samples sizes grow to infinity, among these asymptotically biased parameters are path coefficients, indicator weight and indicators loading (Kock, 2018).

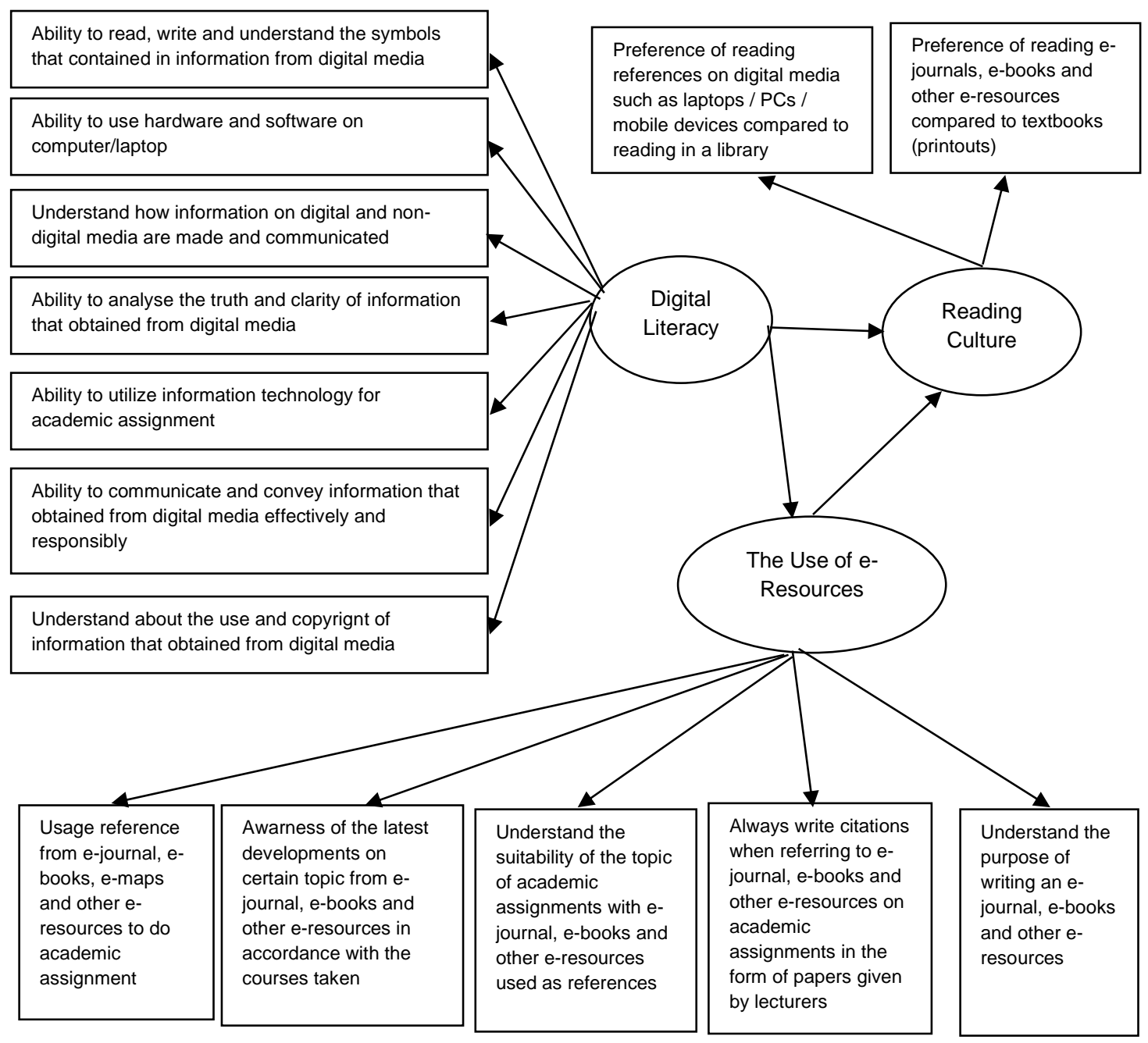

Figure 1: Specified Relationship model between Digital Literacy, The Use of eResources and Reading Culture of Students based on Previous Studies.

\section{Covariance Based-Structural Equation Modeling (CB-SEM) 2.1 Model Specification}

Model specification is making a path diagram (Figure 2) that illustrates the relationship between exogenous and endogenous variables (structural model) and the relationship 
between exogenous and endogenous variables on each indicator (measurement model). The indicators of constructs for digital literacy, the use of e-resources and reading cultures of students showed in Figure 1 and Table 1 . The relationship model between digital literacy $\left(\xi_{1}\right)$ and the use of e-resources $\left(\eta_{1}\right)$ formed based on Nurjanah et. Al (2017), Egberongbe (2011), Noreh (2009), Bala (2016), Madondo et al. (2017) and Akussah et al. (2015). The relationship model between the use of e-resources ( $\left.\eta_{1}\right)$ and the reading culture $\left(n_{2}\right)$ formed based on Bala (2016), Ajayi (2014) and Akpokodje et al (2016). The relationship model between digital literacy $\left(\xi_{1}\right)$ and the reading culture $\left(\eta_{2}\right)$ formed based on Kuniasih (2016), Nurjanah et. Al (2017), Nasrullah et al. (2017) and Yanti (2016).

Table 1: List of construct's indicators.

\begin{tabular}{|c|c|c|c|}
\hline Construct & No & Indicator & Notation \\
\hline \multirow{7}{*}{$\begin{array}{l}\text { Digital } \\
\text { Literacy } \\
\left(\xi_{1}\right)\end{array}$} & 1 & $\begin{array}{l}\text { Ability to read, write and understand the symbols } \\
\text { that contained in information from digital media }\end{array}$ & $\mathrm{X}_{1}$ \\
\hline & 2 & $\begin{array}{l}\text { Ability to use hardware and software on } \\
\text { computer/laptop }\end{array}$ & $\mathrm{X}_{2}$ \\
\hline & 3 & $\begin{array}{l}\text { Understand how information on digital and non- } \\
\text { digital media are made and communicated }\end{array}$ & $X_{3}$ \\
\hline & 4 & $\begin{array}{l}\text { Ability to analyze the truth and clarity of information } \\
\text { that obtained from digital media }\end{array}$ & $X_{4}$ \\
\hline & 5 & $\begin{array}{l}\text { Ability to utilize information technology for an } \\
\text { academic assignment }\end{array}$ & $X_{5}$ \\
\hline & 6 & $\begin{array}{l}\text { Ability to communicate and convey information that } \\
\text { obtained from digital media effectively and } \\
\text { responsibly }\end{array}$ & $X_{6}$ \\
\hline & 7 & $\begin{array}{l}\text { Understand the use and copyright of information } \\
\text { that obtained from digital media }\end{array}$ & $X_{7}$ \\
\hline \multirow{5}{*}{$\begin{array}{l}\text { The Use of } \\
\text { e-Resources } \\
\left(\eta_{1}\right)\end{array}$} & 1 & $\begin{array}{l}\text { Usage reference from e-journal, e-books, e-maps } \\
\text { and other e-resources to do academic assignment }\end{array}$ & $\mathrm{Y}_{1}$ \\
\hline & 2 & $\begin{array}{l}\text { Awareness of the latest developments on a certain } \\
\text { topic from e-journal, e-books, and other e- } \\
\text { resources in accordance with the courses taken }\end{array}$ & $Y_{2}$ \\
\hline & 3 & $\begin{array}{l}\text { Understand the suitability of the topic of academic } \\
\text { assignments with e-journal, e-books and other e- } \\
\text { resources used as references }\end{array}$ & $Y_{3}$ \\
\hline & 4 & $\begin{array}{l}\text { Always write citations when referring to an e- } \\
\text { journal, e-books and other e-resources on } \\
\text { academic assignments in the form of papers given } \\
\text { by lecturers }\end{array}$ & $\mathrm{Y}_{4}$ \\
\hline & 5 & $\begin{array}{l}\text { Understand the purpose of writing an e-journal, e- } \\
\text { books and other e-resources }\end{array}$ & $Y_{5}$ \\
\hline \multirow[t]{2}{*}{$\begin{array}{l}\text { Reading } \\
\text { Culture } \\
\left(\mathbf{n}_{2}\right)\end{array}$} & 1 & $\begin{array}{l}\text { Preference of reading references on digital media } \\
\text { such as laptops / PCs / mobile devices compared } \\
\text { to reading in a library }\end{array}$ & $\mathrm{Y}_{6}$ \\
\hline & 2 & $\begin{array}{l}\text { Preference of reading e-journals, e-books and other } \\
\text { e-resources compared to textbooks (printouts) }\end{array}$ & $Y_{7}$ \\
\hline
\end{tabular}




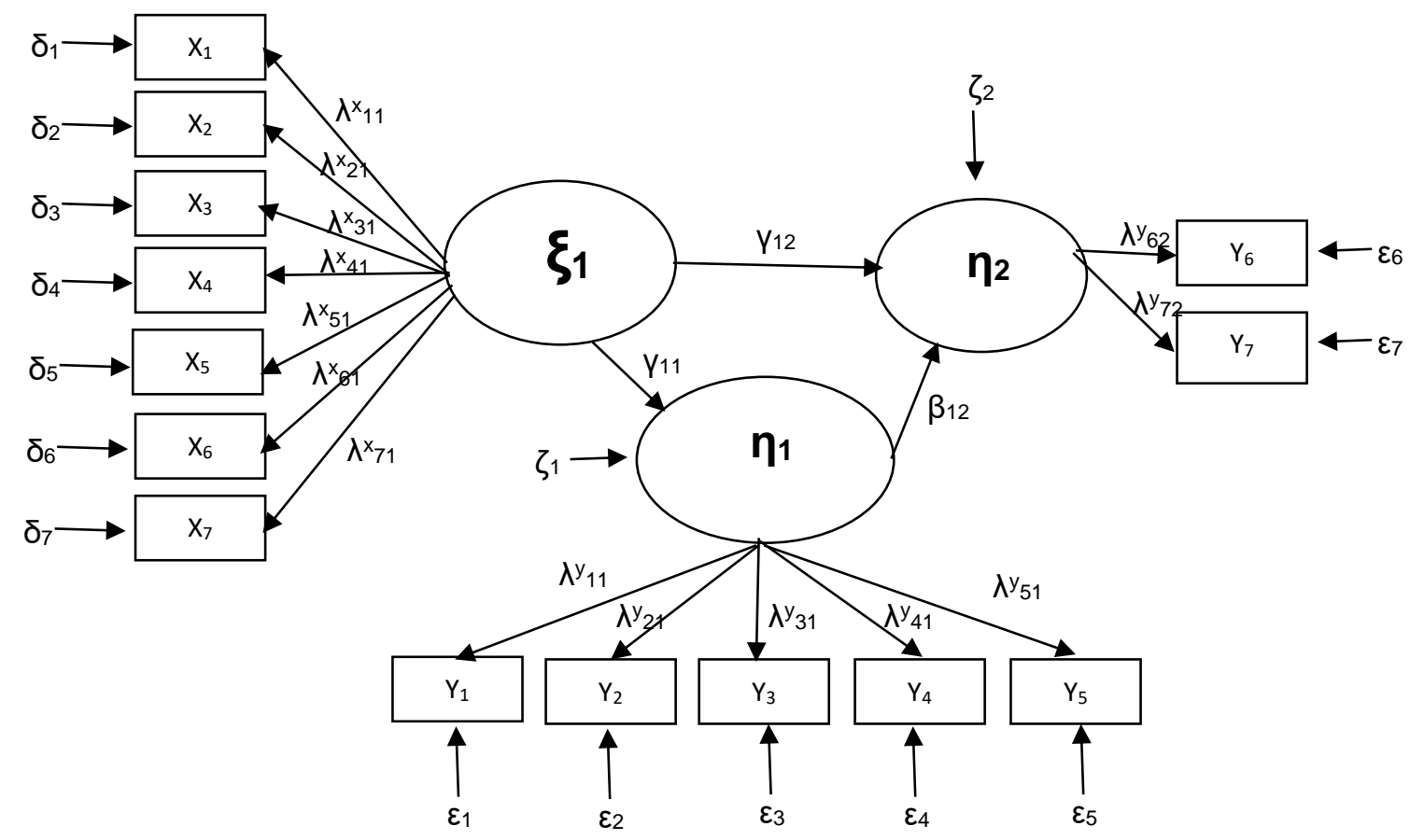

Figure 2: Model specification.

From the model specification (Figure 2.) we get the measurement model as seen at Table 2 and the structural model is seen in Table 3.

\section{$2.2 \quad$ Model Identification}

Model identification related to the direction of whether a model has enough information to get a solution for the model's parameters to be estimated. Model identification can be done using:

$$
d f=\frac{(p+q)(p+q+1)}{2}-t
$$

$(p+q)$ is the number of indicators of exogenous and endogenous variables, $t$ is the number of parameters to be estimated or all paths include the variances of all exogenous variables and errors. If $d f<0$ then the model is under-identified, $d f=0$ then the model is just-identified and with $d t>0$ the model is over-identified. From Figure 2 and using equation (1), the model in this study give $d f=72$ or an over-identified model.

An under-identified model is a model that has more unknown than known information, which it is impossible to get a unique estimate of all the model's parameters (Hoyle, 2012). A model called a just-identified model if there is an equal amount of known and unknown information, and because of this equality, it is possible to derive a unique estimate for all the model's parameters. A just-identified model is also called as a saturated model (Hoyle, 2012). Unlikely an under-identified model, an over-identified model has more known information than unknown information, which it is possible to get the estimate of all the model's parameters using several equations from the known information. Only over-identified models provide fit statistics as a means of evaluating the fit of the overall model (Hoyle, 2012). 
Table 2: Measurement model.

\begin{tabular}{lc}
\hline \multicolumn{1}{c}{ Construct } & Measurement Model \\
\hline Digital Literacy & $X_{1}=\lambda_{11}^{X} \xi_{1}+\delta_{1}$ \\
$X_{2}$ & $=\lambda_{21}^{X} \xi_{1}+\delta_{2}$ \\
$X_{3}$ & $=\lambda_{31}^{X} \xi_{1}+\delta_{3}$ \\
$X_{4}$ & $=\lambda_{41}^{X} \xi_{1}+\delta_{4}$ \\
$X_{5}$ & $=\lambda_{51}^{X} \xi_{1}+\delta_{5}$ \\
$X_{6}$ & $=\lambda_{61}^{X} \xi_{1}+\delta_{6}$ \\
& $X_{7}=\lambda_{71}^{X} \xi_{1}+\delta_{7}$ \\
\hline \multirow{5}{*}{ The Use of E-Resources } & $Y_{1}=\lambda_{11}^{y} \eta_{1}+\varepsilon_{1}$ \\
& $Y_{2}=\lambda_{21}^{y} \eta_{1}+\varepsilon_{2}$ \\
$Y_{3}$ & $=\lambda_{31}^{y} \eta_{1}+\varepsilon_{3}$ \\
& $Y_{4}=\lambda_{41}^{y} \eta_{1}+\varepsilon_{4}$ \\
$Y_{5}$ & $=\lambda_{51}^{y} \eta_{1}+\varepsilon_{5}$ \\
\hline Reading Culture & $Y_{6}=\lambda_{62}^{y} \eta_{2}+\varepsilon_{6}$ \\
& $Y_{7}=\lambda_{72}^{y} \eta_{2}+\varepsilon_{7}$ \\
\hline
\end{tabular}

Table 3: Structural model.

\begin{tabular}{lc}
\hline \multicolumn{1}{c}{ Construct } & Measurement Model \\
\hline The Use of E-Resources & $\eta_{1}=\gamma_{11} \xi_{1}+\zeta_{1}$ \\
Reading Culture & $\eta_{2}=\gamma_{12} \xi_{1}+\beta_{12} \eta_{1}+\zeta_{2}$ \\
\hline
\end{tabular}

\subsection{Parameter Estimation Method}

Parameters of the model (Figure 2) are estimated iteratively by using the Maximum Likelihood (ML) method and LISREL. ML is a normal theory method which assumes multivariate normality for the joint population distribution of endogenous variables, given exogenous variables, it describes principle which underlies derivation of parameter estimates that maximize the likelihood which data were drawn from this population (Kline, 2016). Under the assumption, the ML estimator is asymptotically consistent, unbiassed, efficient and normally distributed, and the model fit statistic is asymptotically distributed as chi-square with $d f=p(p+1) / 2-t$, where $t$ is the number of model parameters estimated (Hoyle, 2012). A consistent estimator is an estimator that approaches the true parameter when sample size increases toward infinity. An unbiased estimator is an estimator which its expected value (the averages of estimates from an infinity number of independent samples from the same population) equals to population parameter. An estimator called efficient if it has smallest variability among consistent estimators.

\section{$2.4 \quad$ Model Fit Testing}

A model fit testing consists of a measurement model assessment, structural model assessment, and global fit testing. The aims of the measurement model assessment to evaluate validity and reliability of indicators using standardized loading, composite reliability and average variance extracted (AVE). Indicators of latent variables are valid 
if the standardized loading higher than 0.7 , but others stated that the standardized loading which lies on between 0.5 to 0.6 still acceptable. At the same time, composite reliability used to evaluate the reliability of latent variables. Composite reliability values are range from 0 to 1 , the higher value indicates a higher level of reliability. To say a latent variable is reliable, the composite reliability value must greater than or equal to 0.6. In addition, the reliability of latent variables can be measured using AVE which must greater than 0.5. If the AVE less than 0.5, it means that the measurement errors give more contribution to the indicators than to the latent variable.

The structural model assessment focuses on the significance of the relationships between exogenous $(\xi)$ and endogenous $(\eta)$ latent variables and the relationship among the endogenous variables using $t$-values and $R^{2}$. The critical value of $t$-values for the two-tailed hypothesis with a significance level (a) $10 \%, 5 \%$, and $1 \%$ are 1.65 , 1.96 and 2.57. The $R^{2}$, a coefficient of determination indicates the amount of variance on endogenous latent variables that can be explained simultaneously by independent latent variables. The higher $R^{2}$ means a better structural equation obtained.

Global fit testing focuses on assessing the goodness-of-fit of the overall model. Goodness-of fit evaluate how well the specified model reproduces observed covariance matrix among the indicators (Hair, Black, et al., 2014). Goodness-of fit test carried out using Chi-Square with cut off $p$-value $>0.025$ for significance level $5 \%$, Root Mean Square Error of Approximation (RSMEA) that must lies on range 0.03 to 0.08 for confidence interval 95\% (Hair, Black, et al., 2014), Normed Fit Index (NFI), Comparative Fit Index (CFI), Incremental Fit Index (IFI) and Relative Fit Index (RFI). $\mathrm{NFI}, \mathrm{CFI}$, IFI and RFI range between 0 and 1 and a model with perfect fit would produce values near to 1 .

\subsection{Modification Model}

Model modification is considered if the fit of the model being evaluated is considered inadequate. The goal of model modification is to improve the fit of the model. One of the ways in the model modification is letting the error of a few indicators correlated. This will reduce Chi-square and increasing other goodness-of-fit statistics, which means improving the fit of the model.

\section{Results and Discussion}

This study took data from 256 questionnaires of students at STMIK Sumedang. CBSEM analysis performed using LISREL 10.10 Student version. The parameter estimators can be seen in Figure.3.

Measurement model assessment signifies that all the standardized loading of all indicators lies between 0.52 to 0.79 (Figure 4) which means all indicators of digital literacy, reading culture and the use of e-resources are valid. Furthermore, composite reliability of digital literacy and the use of e-resources are greater than 0.6 but composite reliability of reading culture is quite small (Table 4). Even though the composite reliability of reading culture was less than 0.6 , we tend to keep the indicators of this variable in the model (Figure 2). Due to this variable only has two indicators, then one or more indicators removed, we would lose the information about this variable. For the same reason, despite all the AVE are less than 0.5 with only a small gap (Table 4), we keep all the indicators of the model (Figure 2). 


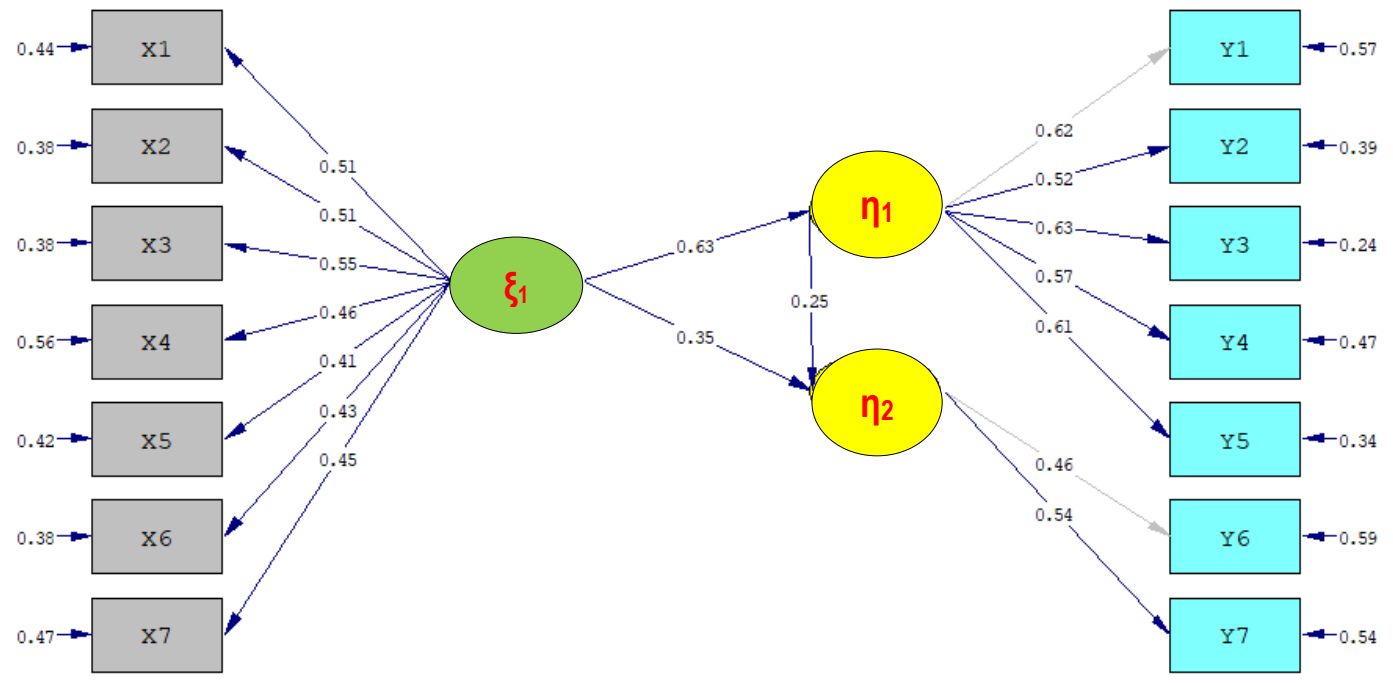

Figure 3: Parameter's estimator of the model.

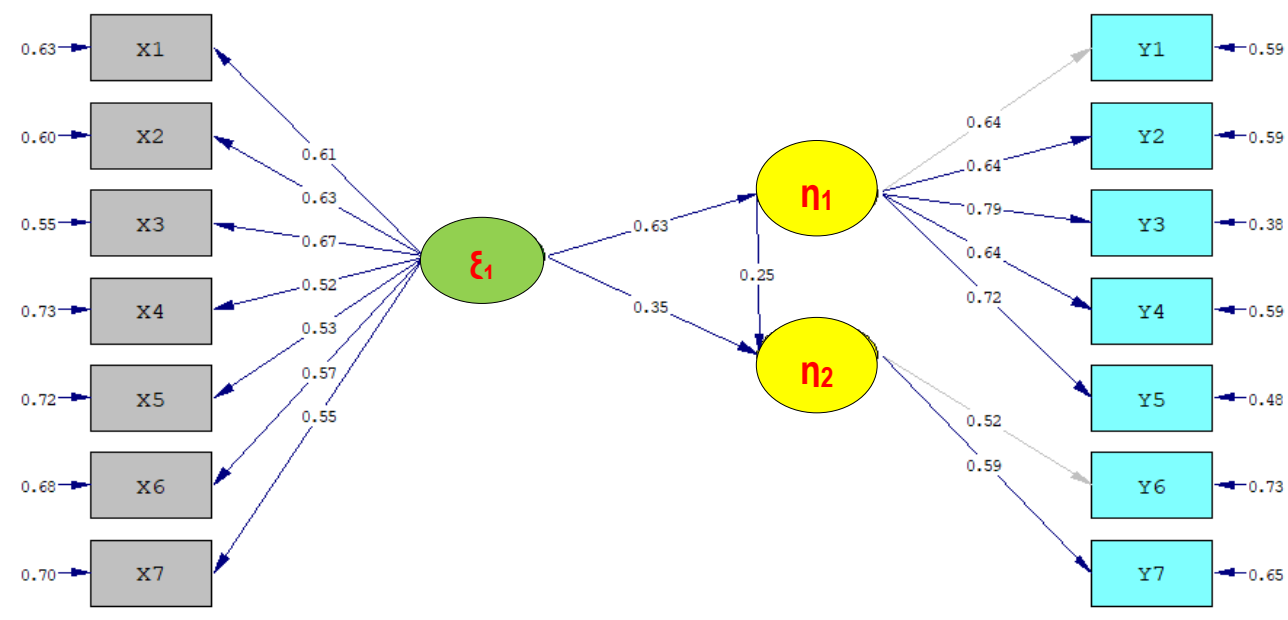

Figure 4: Standardized solutions.

Table 4: Composite reliability and AVE.

\begin{tabular}{lcc}
\hline \multicolumn{1}{c}{ Variable } & $\begin{array}{c}\text { Composite } \\
\text { Reliability }\end{array}$ & $\begin{array}{c}\text { Average Variance } \\
\text { Extracted (AVE) }\end{array}$ \\
\hline Digital Literacy & 0,864 & 0,343 \\
The Use of E-Resources & 0,817 & 0,473 \\
Reading Culture & 0,470 & 0,308 \\
\hline
\end{tabular}

Table 5: Total effect to digital literacy.

\begin{tabular}{lcc}
\hline \multicolumn{1}{c}{ Variable } & Direct Effect & Indirect Effect \\
\hline The Use of E-Resources & 0.635 & \\
Reading Culture & 0.510 & 0.157 \\
\hline
\end{tabular}




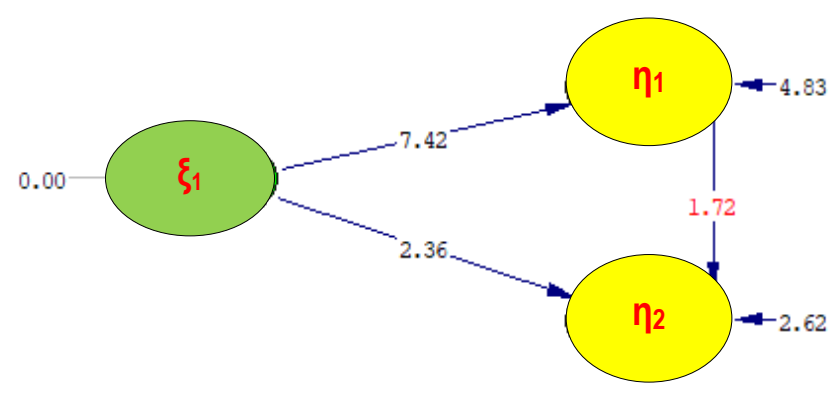

Figure 5: T-Values of structural model.

From the structural model assessment, with t-values higher than 1.96 (Figure 5), digital literacy significant influences on the use of e-resources and reading culture of students. Meanwhile, the use of e-resources does not significant influences on the reading culture of students because the t-values are less than 1.96 (Figure 5). The significant relationship between digital literacy and the use of e-resources suggests the same relationship model obtained by Nurjanah et. Al (2017), Egberongbe (2011), Noreh (2009), Bala (2016), Madondo et al. (2017) and Akussah et al. (2015). The significant relationship between digital literacy and reading culture indicates the same output which showed by Kuniasih (2016), Nurjanah et.al (2017), Nasrullah et al. (2017) and Yanti (2016) as well. In contrast, the significance test indicates a different outcome of the relationship model between the use of e-resources and the reading culture explained by Bala (2016), Ajayi (2014) and Akpokodje et al (2016). The variance of the use of e-Resources and reading culture of students influenced by digital literacy in $40.3 \%$ and $26.1 \%$ with the total effect of 0.635 and 0.51 (Table 5). Whereas only $29,7 \%$ the variance of reading culture of students simultaneously influenced by digital literacy and the use of resources.

Table 6: Goodness-of-fit statistics.

\begin{tabular}{lccc}
\hline \multicolumn{1}{c}{ Statistics } & Values & Cut-off & Results \\
\hline Chi-Square & 165.274 & P-value $>0.025$ & Does not Fit \\
RMSEA & 0.0694 & $<0.05$ & Does not Fit \\
NFI & 0.842 & $>0.9$ & Acceptable \\
CFI & 0.905 & $>0.9$ & Fit \\
IFI & 0.907 & $>0.9$ & Fit \\
RFI & 0.807 & $>0.9$ & Acceptable \\
\hline
\end{tabular}

Further analysis depicts goodness-of-fit the overall model (Table 6). The results suggest improving the fit of the model. Therefore, we need a model modification which is letting the error of a few indicators correlated (Figure 6). The modification model performed goodness-of-fit statistics which is not only reducing Chi-square and RSMEA but also increasing NFI, CFI, IFI, and RFI (Table 7). The changes of these values mean improving the fit of the model (Table 8 and Table 9). 
Table 7: Goodness-of-fit statistics of modification model.

\begin{tabular}{lccc}
\hline \multicolumn{1}{c}{ Statistics } & Values & Cut-off & Results \\
\hline Chi-Square & 109.553 & P-value $>0.025$ & Does not Fit \\
RMSEA & 0.0489 & $<0.05$ & Does not Fit \\
NFI & 0.896 & $>0.9$ & Acceptable \\
CFI & 0.957 & $>0.9$ & Fit \\
IFI & 0.958 & $>0.9$ & Fit \\
RFI & 0.861 & $>0.9$ & Acceptable \\
\hline
\end{tabular}

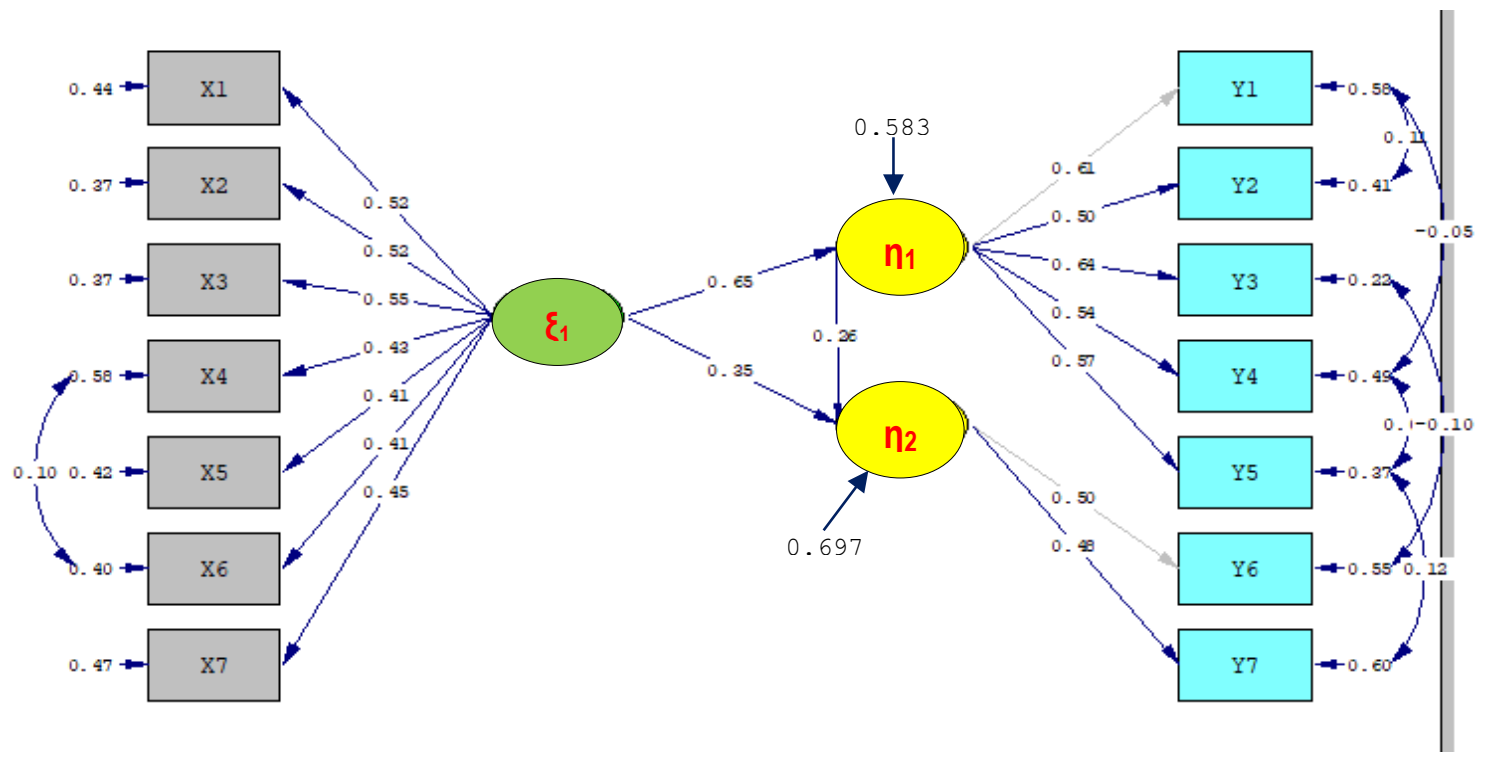

Figure 6: Parameter estimator of modification model.

Then from the estimation of the modification model's parameters (Figure 6), we get the fitted measurement model as seen in Table 8.

Table 8: The Fitted measurement model.

\begin{tabular}{cc}
\hline Construct & Measurement Model \\
\hline Digital Literacy & $X_{1}=0.52 \xi_{1}+0.44$ \\
$X_{2}=0.52 \xi_{1}+0.37$ \\
$X_{3}=0.55 \xi_{1}+0.37$ \\
$X_{4}=0.463+0.58$ \\
$X_{5}=0.41 \xi_{1}+0.42$ \\
$X_{6}=0.41 \xi_{1}+0.40$ \\
$X_{7}=0.45 \xi_{1}+0.47$ \\
\hline The Use of E-Resources & $Y_{1}=0.61 \eta_{1}+0.58$ \\
& $Y_{2}=0.50 \eta_{1}+0.41$ \\
& $Y_{3}=0.64 \eta_{1}+0.22$ \\
& $Y_{4}=0.54 \eta_{1}+0.49$ \\
& $Y_{5}=0.57 \eta_{1}+0.37$ \\
\hline Reading Culture & $Y_{6}=0.50 \eta_{2}+0.55$ \\
& $Y_{7}=0.48 \eta_{2}+0.60$ \\
\hline
\end{tabular}


Whereas the fitted structural model is seen in Table 9.

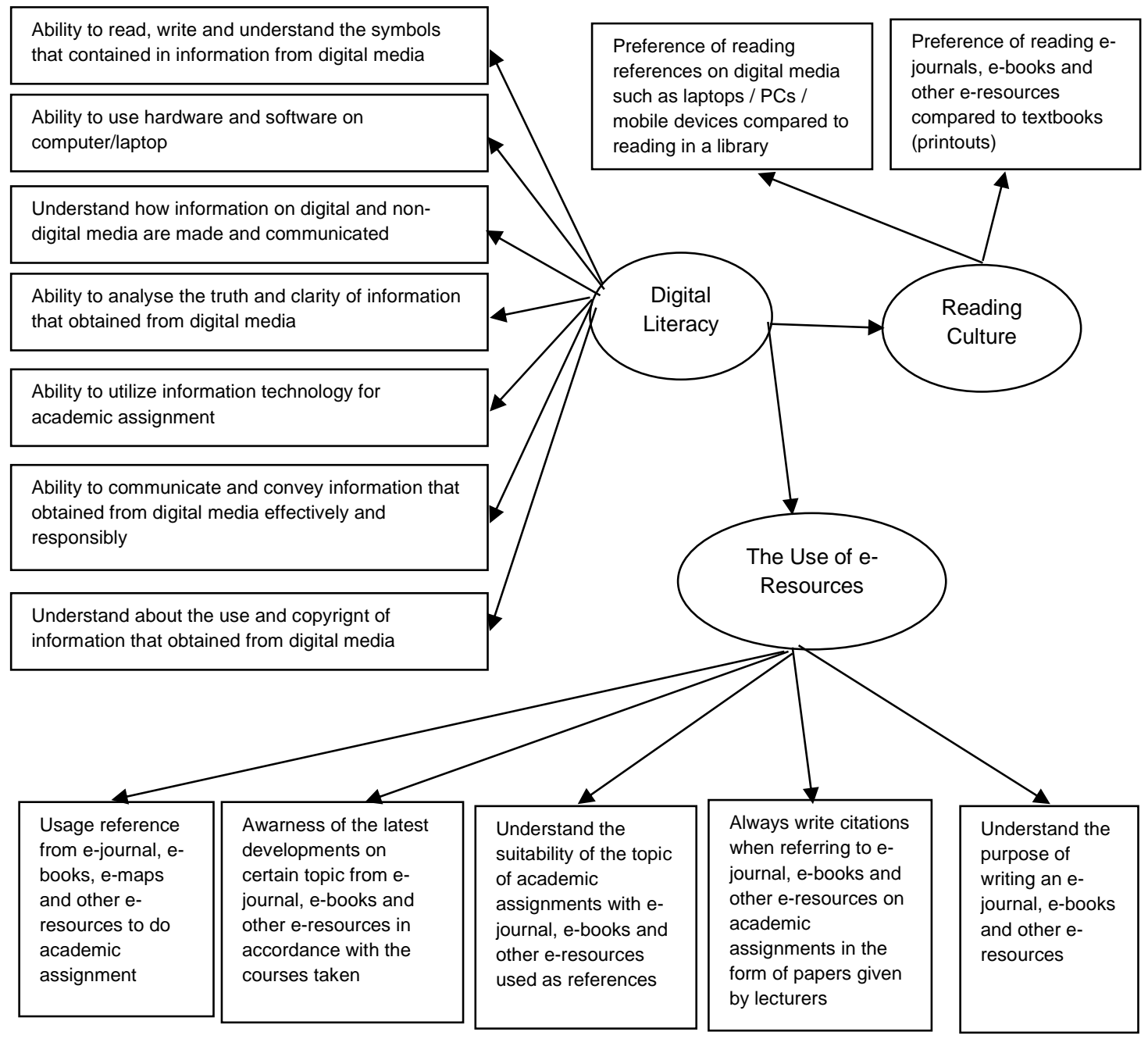

Figure 7: Fit model of the Relationship between Digital Literacy, The Use of eResources and Reading Culture of Students.

Table 9: The Fitted Structural Model

\section{Construct}

The Use of E-Resources
Reading Culture

\section{Measurement Model}

$$
\begin{gathered}
\eta_{1}=0.65 \xi_{1}+0.583 \\
\eta_{2}=0.35 \xi_{1}+0.26 \eta_{1}+0.697
\end{gathered}
$$

\section{Conclusions}

Based on the CB-SEM analysis that has been performed, the simultaneous relationship model between digital literacy, the use of e-resources and the reading culture of students with each indicator is illustrated in Figure 7. There is a significant influence of digital literacy on the use of e-resources and the reading culture of students. In addition, due to differences in the outcome obtained in the previous study, we need further analysis of the relationship between the use of e-resources and reading culture. 
Acknowledgment. The deepest gratitude to the Ministry of Research, Technology and Higher Education, Directorate General of Strengthening Research and Development, Republic of Indonesia, for research aid funds through PDP Program, 2019.

\section{References}

Abubakar, D. (2015). Influence of Computer Literacy on Postgraduates ' Use of EResources in Nigerian University Libraries. Library Philosophy and Practice, 1-17.

Adeleke, D. S., Ivo, K., \& Nwalo, N. (2017). Availability, Use and Constraints to Use of Electronic Information Resources by Postgraduates Students at the University of Ibadan. International Journal of Knowledge Content \& Technology, 7(4): 51-69.

Ajayi, S. A. (2014). The Influence of Electronic Resources Use on Students' Reading Culture in Nigerian Universities: A Case Study of Adeleke University EDE, Osun State, 1182.

Akpokodje, V. N., \& Ukwuoma, S. C. (2016). Evaluating the impact of eBook on reading motivation of students of higher learning in Nigerian Universities. Columbus IFLA WLIC, 1-15.

Akussah, M., \& Adu-sarkodee, R. (2015). Impact of Electronic Resources and Usage in Academic Libraries in Ghana : Evidence from Koforidua Polytechnic \& All Nations University College, Ghana. Journal of Education and Practice, 6(33): 33-38.

Ani, O. E., Ngulube, P., \& Onyancha, B. (2015). Perceived Effect of Accessibility and Utilization of Electronic Resources on Productivity of Academic Staff in Selected Nigerian Universities. https://doi.org/10.1177/2158244015607582.

Bala, S. (2016). Usage of Electronic Resources and Their Impact on Reading Culture: A Case Study of Punjab Agricultural University, Ludhiana. International Journal of Digital Library Services, 6(3): 59-66.

Egberongbe, H. S. (2011). The Use and Impact of Electronic Resources at the University of Lagos The Use and Impact of Electronic Resources at the University of Lagos. Library Philosophy and Practice, 472.

Hair, J. F., Black, W. C., Barbin, B. J., \& Anderson, R. E. (2014). Multivariate Data Analysis: Pearson New International Edition (Seventh Ed). Harlow (UK): Pearson Education Limited.

Hair, J. F., M.Hult, G. T., M.Ringle, C., \& Sarstedt, M. (2014). Partial Least Squares Structural Equation Modeling (PLS-SEM) (Vicki Knight, Ed.). US: SAGE Publications, Inc.

Hoyle, R. H. (2012). Structural Equation Modeling. New York (US): The Guilford Press.

Imsong, L. (2016). Usage of Electronic- Resources in Academic Libraries and Role. 10th Convention PLANNER 2016: 31-35.

Jr, J. F. H., Hopkins, L., Georgia, M., \& College, S. (2014). Partial Least Squares Structural Equation Modeling ( PLS-SEM ) An Emerging Tool in Business Research. European Business Review, 26(2): 106-121. 
Kline, R. B. (2016). Principles and Practice of Structural Equation Modeling (Fourth; T. D.Little, Ed.). New York (UK): The Guilford Press.

Kock, N. (2018). From composites to factors: Bridging the gap between PLS and covariance - based structural equation modelling. Info System J., 29(3): 674-706. https://doi.org/10.1111/isj.12228.

Kurniasih, N. (2016). Reading Habit in Digital Era: Indonesian People do not Like Reading, is it. Web Culture Forum'Site, 1-3.

Kurniawati, J., \& Baroroh, S. (2016). Literasi Media Digital Mahasiswa Universitas Muhammadiyah Bengkulu. Jurnal Komunikator, 8(2): 51-66.

Madondo, T., Sithole, N., \& Chisita, C. T. (2017). Use of Electronic Information Resources by Undergraduate Students in the Faculty of Management and Administration at. Asian Research Journal of Arts \& Social Sciences, 2(2): 1-12. https://doi.org/10.9734/ARJASS/2017/29633.

Nasrullah, R., Aditya, W., Satya, T. I., Nento, M. N. N. H., Miftahussuri, \& Akbari, Q. S. (2017). Literasi Digital , Gerakan Literasi Nasional (Dr. L. A. Mayani, Ed.). Jakarta (ID): Kementrian Pendidikan dan Kebudayaan.

Noreh, A. (2009). Impact of Electronic Resources on Academic and Research Programs of the University. In Library and Information Research. University of Nairobi.

Nurjanah, E., Rusmana, A., \& Yanto, A. (2017a). Hubungan Literasi Digital Dengan Kualitas Penggunaan E-Resources. Lentera Pustaka, 3(2): 117-140.

Nurjanah, E., Rusmana, A., \& Yanto, A. (2017b). Hubungan literasi digital dengan kualitas penggunaan e-resources. Lentera Pustaka: Jurnal Kajian IImu Perpustakaan, Informasi Dan Kearsipan, 3(2): 117-140.

Periyeti. (2017). Usaha Meningkatkan Minat Baca Mahasiswa. Jurnal Pustaka Budaya, 4(1): 55-67.

Sapril. (2010). Budaya Membaca Masyarakat Kampus. Jurnal Iqra', 4(01): 66-69.

Wong, K., \& Wong, K. (2013). Partial Least Squares Structural Equation Modeling (PLS-SEM) Techniques using SmartPLS. Marketing Buletin, 24, Technical Note 1, 1-32. https://doi.org/10.1128/AEM.01914-13.

Yanti, M. (2016). Determinan Literasi Digital Mahasiswa : Kasus Universitas Sriwijaya. Buletin Pos Dan Telekomunikasi, 14(2): 79-94. https://doi.org/10.17933/bpostel.2016.140202. 